\title{
BOODSCHAP VAN PROFESSOR DR. J. WATERINK
}

ter gelegendheid van die verlening aan hem van de graad Doctor Educationis, honoris causa, door de Universiteit voor Christelijk Hoger Onderwijs te Potchefstroom op Zaterdag, 26 Maart 1955, en op die day voorgelezen door de heer Jan van den Berg, Buitengewoon en Gevolmachtigd Ambassadeur van Hare Majesteit de Koningin der Nederlanden.

Miinheer, de Kanselier, Mijnheer de Voorzitter van de Raad, Mijnheer de Vice-Kanselier en Rector, overige Heren ambtsdragers, en grij allen, die herwaarts kwaamt ter gelegenheid van deze Gradendag, zeer geachte en zeer gewenste toehoorders.

Het is mij een angrijpende, en tevens zeer vererende gedachte, dat $i k$ in deze ure, hoewel in absentia, tot $U$ het woord mag voeren. Dat mijn woord $U$ wordt overgebracht door de Ambassadeur van Hare Majesteit de 
Koningin der Nederlanden, die behalve dat, ook een trouw vriend van Uw vaderland en Uw Universiteit is, en aan wie ik mij door banden van vriendschap gebonden weet, vergoedt mij veel van dit gemis, dat ik gevoel, omdat ik niet persoonlijk bij U kan zijn.

Allereerst dan een woord van hartelijke en diep gevoelde dank voor de eer, welke $U$ mij heeft aangedaan door $U_{w}$ besluit mij te benoemen tot Doctor Educationis honoris causa en mij geschonken door Uw Raad en door Uw Senaat.

Dat ik de hoogste eer, die Uwe Universiteit iemand kan verlenen, deel met onze onvergetelijke Totius, en met $U w$ zo eminente kanselier dr. F. J. $\mathrm{du}$ Toit, is voor mij als een wonder.

Dat juist de Universiteit van Potchefstroom mij dit eredoctoraat toedacht, is voor mij een van de mooiste dingen, die mij in mijn leven konden toevallen.

Wanneer ik thans de vier gronden, die gij genoemd hebt in de brief, waarmee gij mij mededeelde mij dit ere-doctoraat te hebben verleend, naga, dan wil ek gaarne zwijgen over wat gij noemt mijn ,wetenschappelijke prestatie op het gebied van die Christelijke wetenschap".

Indien ik door Gods goedheid iets heb mogen doen, dan is dit op zichzelf niet anders geweest dan de vervulling van mijn plicht. En ook hier geldt het woord: „Wat hebt gij, wat gij niet hebt ontvangen?”

Eenzelfde opmerking zou ik willen maken over mijn arbeid aan de Vrije Universiteit. Als onder Gods bestel mij vandaag van Uw zijde ere gewordt, dan wil ik dit gaarne zo ziet, dat God in zijn Koninkrijk genade en ere pleegt saam te voegen.

Misschien mag ik iets meer zeggen over de ander gronden die gij noemt. Mijn vriendschap voor het Afrikaner-volk en mijn liefde voor Uw Universiteit. Ik zie dit werkelijk niet als iets aparts, of iets dat op zichzelf verdienstelijk is. Immers er kan geen verdienste liggen in het feit, dat iemand hen, die in natuurlijk en geestelijk opzicht zijn naaste familie zijn, lief heeft.

Naar mijn vaste overtuiging heeft het volk, dat met Nederland stamverwant en taalverwant is, en dat naar de stem van Zuid-Afrika heeft leren luisteren en die heeft leren verstaan, een kostelijke schat van Nederlandse traditie en van Calvinistisch idealisme geplant in de Zuid-punt van Afrika.

Beide, Uw afkomst en Uw geloofsovertuiging, hebt gij begrepen. Gij hebt verstaan welk een roeping daaruit voortsproot. En het begrijpen van die roeping geeft $\mathrm{U}$ een geweldige taak. 
Als ik denk aan Uw groten, en aan Je groten in Uw kring-en als ik dat doe mag ik toch zeker de namen noemen van Totius, van professor Postma en van Joon van Rooy, om van de levenden maar niet ie spreken-dan kan ik niet anders dan met bewondering opzien naar een volk, dat ik als tien-jarige jongen reeds leerde lief krijgen, toen wij dagelijks meeleefden met de strijd, die bij het ontwaken van deze eeuw de hele wereld in spanning hield.

De enorme snelheid, waarmee gij $U$ een cultuur hebt opgebouwd, niet alleen kenbaar in de groei van Uw steden, maar ook in de bloei van Uw Universiteiten, moet ieder cultuur-volk tot verbazing brengen. En het zou wel heel ondankbaar zijn, wanneer Nederlanders niet zagen welk een kostelijke loot aan de aloude stam hier uitbotte en tot bloei en tot vruchtdragen kwam.

En dat gij dan als universiteit van Potchefstroom in dit land het vaandel van het Calvinisme hoog opheft en met moed, beleid en trouw de beginselen, die ons in de ziel geworteld zijn, uitdraagt - dat is oorzaak dat het hart van Uw Nederlandse broeders en zusters blijde klopt, wanneer de naam Potchefstroom wordt genoemd.

En waar ik het zo zie, daar zult gij kunnen begrijpen, dat mijn liefde voor Uw volk en voor $U w$ universiteit voor mijn besef zo natuurlijk en de aller Christelijkste zaak van de wereld is, zoals men lief heeft de koestering van het hart van een vriend, die met $U$ op reis is naar eenzelfde einddoel, dwars door de woestijn.

Een enkel woord nog over Uw toekomst. Wij weten niet wat God besloten heeft over zijn wereld, in dit tijdperk van koude oorlogen en atoombommen. Maar wij weten wel, dat het goed is om zijn vaderland lief te hebben en op God te vertrouwen in gehoorsaamheid aan zijn woord. Wij weten dat wij ook op het erf van de wetenschap „een strijd te strijden en een natie te leiden hebben". En wij weten bovendien dat het eind, of het nu over honderd of over tien duizend jaar is, dat weten wij nie, maar dat het eind, wanneer het komt, ons waakzaam en trouw zal moeten vinden. Wat kan ik $U$ dan beter wensen, als volk en als universiteit, dan de betrachting van deze waakzaamheid en deze trouw?

Waakzaamheid is beter dan strijdlust, want zij sluit desnoods strijdlust in, maar daarin is ook altijd de gedachte aan de vrede.

Trouw is meer dan liefde, want trouw sluit de liefde in, maar gelooft ook de duurzaamheid in de levenshouding en in het gedrag, die een staagr geloof betekenen voor heel de toekomst. Een rijk gezegende toekomst, waarin de weg van Uw waakzaamheid en trouw $U w$ deel is, tot eer van Hem, uit Wien, door Wien en tot Wien alle dingen zijn en Die alleen toekomt de eer en de heerlikheid. 